\title{
The Complexity of Co-Infections in the Era of COVID-19
}

\author{
Nevio Cimolai ${ }^{1,2}$ (D) \\ Accepted: 13 April 2021 / Published online: 23 April 2021 \\ (C) The Author(s), under exclusive licence to Springer Nature Switzerland AG 2021
}

\begin{abstract}
The current frequency of COVID-19 in a pandemic era ensures that co-infections with a variety of co-pathogens will occur. Generally, there is a low rate of bonafide co-infections in early COVID-19 pulmonary infection as currently appreciated. Reports of high co-infection rates must be tempered by limitations in current diagnostic methods since amplification technologies do not necessarily confirm live pathogen and may be subject to considerable laboratory variation. Some laboratory methods may not exclude commensal microbes. Concurrent serodiagnoses have long been of concern for accuracy in these contexts. Presumed virus co-infections are not specific to COVID-19. The association of influenza viruses and SARS-CoV-2 in co-infection has been considerably variable during influenza season. Other respiratory virus co-infections have generally occurred in less than $10 \%$ of COVID-19 patients. Early COVID-19 disease is more commonly associated with bacterial co-pathogens that typically represent usual respiratory micro-organisms. Late infections, especially among severe clinical presentations, are more likely to be associated with nosocomial or opportunistic pathogens given the influence of treatments that can include antibiotics, antivirals, immunomodulating agents, blood products, immunotherapy, steroids, and invasive procedures. As anticipated, hospital care carries risk for multi-resistant bacteria. Overall, co-pathogen identification is linked with longer hospital stay, greater patient complexity, and adverse outcomes. As for other viral infections, a general reduction in the use of empiric antibiotic treatment is warranted. Further insight into co-infections with COVID-19 will contribute overall to effective antimicrobial therapies and disease control.
\end{abstract}

Keywords COVID-19 $\cdot$ Coronavirus $\cdot$ Co-infection $\cdot$ Diagnosis

\section{Introduction}

The pandemic of SARS-CoV-2 infection carries with it many nuances regarding epidemiology, microbiology, and clinical manifestations. With intense focus on treatment and prevention, proportionately less weight has been given to understand this virus in the milieu of other human pathogens that may coexist or complicate infections. As for other serious or prolonged respiratory virus infections, it is inevitable that other pathogens will complicate clinical presentations, active disease, diagnostics, and surveillance. This narrative review

This article is part of the Topical Collection on Covid-19

Nevio Cimolai

ncimolai@mail.ubc.ca

1 Faculty of Medicine, The University of British Columbia, Vancouver, Canada

2 Children's and Women's Health Centre of British Columbia, 4480 Oak Street, Vancouver, B.C. V6H3V4, Canada examines various aspects of COVID-19 co-infection and illustrates key lessons that are either newly apparent or simply re-learned but highly relevant.

\section{General Attributes of Viral Infections in the Co-Infection Context}

Upper and lower viral respiratory illnesses are well known to have a variable course. Some may be relatively asymptomatic, and symptomatic disease can vary from 1 day to weeks. Generally, live virus presence during infection is extinguished by approximately 10 days with some exceptions. Past the finding of infectious virus, prolonged illness has the potential to arise due to post-infectious inflammatory residua or structural damage. The latter can also be variable remaining from days to months. More aggressive respiratory disease can be associated with permanent pathology of the affected airways of varying intensity. There is opportunity for co-infection either during acute virus excretion in the early phases or after clinical disease residua are manifest thereafter. Such a 
potential overlap provides credence for the existence of true co-infections or infections superimposed on a previous virus disease.

The vast array of respiratory viral pathogens, and especially in more contagious circumstances such as winter season, school, childhood care, and highly populated co-habitations, ensures that there is plenty of opportunity for co-detections. Co-detections, however, do not always equate with co-infection, and it may at times be quite evident that two proximal clinical infections have occurred in sequence. Residual pathology from the first infection may affect the likelihood, frequency, and/or nature of the disease that arises when the next pathogen emerges. Patient co-morbidities have the potential to influence outcomes. Following from the latter, co-infections may emerge from pathogens that naturally complicate viral infections such as normally resident respiratory bacteria. These may include an enrichment of, or pre-selection for, bacteria or fungi that proliferate during disease or with proclivity to complicate antibiotic treatments or immunologically susceptible patients. In this regard, it would be anticipated that nosocomial infection should complicate COVID-19 as for other viral respiratory infections. The contamination of clinical samples with usual respiratory micro-organisms must be considered in sophisticated analyses [1].

There are many anecdotes of prolonged human endemic coronavirus shedding [2, 3]. Many of these findings are based on non-culture methods and detect viral genome only. Therefore, the concept that such detection may be prolonged when indeed another virus or other pathogen arises is evident.

A collection of studies also find live SARS-CoV-2 excretion well after 10 days, but in the minority [4]. Very prolonged genome shedding as well as anecdotes which find live virus as late as 102 days after disease onset have been detailed [5].

\section{Diagnostic Quandaries}

There are many technical difficulties that may arise in defining diagnoses for co-infections (Table 1). Most findings of coronavirus in clinical samples depend on RNA amplification strategies, and these do not discriminate live and potentially infectious virus from inactive residual virus. Virus may therefore be detected in the presymptomatic state, active infection, or short or prolonged post-infectious resolution [6]. Most often, the context for co-detection will be an active infection whereby the co-pathogen(s) identified is/are from the tail end of excretion due to preceding infection. Many studies of co-virus infection have not used secondary methods to confirm coronavirus detection let alone other viruses [2]. An example of the potential magnitude of this issue is illustrated by the finding in one study of a viral co-pathogen in $96 \%$ of coronavirus detections [7]. It should be emphasized that co- detection or co-diagnosis otherwise does not always amount to co-infection.

Positive indices for genome amplification detection are set at a given standard, and in the absence of confirmatory alternate or repeat testing, they may be relatively arbitrary. There is potential for both under- or over-diagnosis. An adjustment of methodological thresholds can pit sensitivity against specificity. The findings of a high frequency of putative co-infections or the presence of multiple co-existing viral or atypical pathogens should alert the observer to such diagnostic complexity. Variation in methods and diagnostic thresholds also exists between laboratories, thus complicating comparisons. Partial genome amplification technologies can allow for an estimate of coronavirus quantitation, i.e., low thresholds of detection may equate with greater viral load presence. Coronavirus quantitations as estimated by amplification methods were higher for symptomatic patients, and, in two studies, when the coronavirus was the only virus found in samples in contrast to co-infections $[8,9]$. In the work of van der Hoek et al. [10], human endemic respiratory coronavirus NL63 was present in a significantly higher viral load from samples where this virus was identified alone in contrast to those samples where it was found in putative co-infections. In another study, there was no correlation of viral load with severity [11].

In addition, non-genetic amplification diagnostic methods also have their potential foibles. Diagnostic serology has long been cautiously applied in epidemiological studies. Dependence on IgM serology in particular has raised issues with non-specificity. Detection of viral antigen through immunoassay or through direct immunofluorescence assays can also be susceptible to sensitivity or observer technological limitations. For example, viral antigen detection is of greater sensitivity when the infection is at a peak and when viral quantitation is near its peak.

\section{The Example of Putative Mycoplasma pneumoniae Co-Infection with SARS-CoV-2}

True co-infections with M. pneumoniae will inevitably occur due to the frequency of the bacterium as a common cause of community-acquired respiratory infection in children and relatively young adults throughout the world [12]. Several publications detail possible co-infections for SARS-CoV-2 and M. pneumoniae [13-22]. There are several methodological issues arising however which complicate the validity and applications (Table 2). The large tally of such infections in one COVID-19 cohort seems unlikely however to represent bonafide co-infection [13]. The latter reported that over onehalf of COVID-19 infections admitted to hospital were seropositive for M. pneumoniae-IgM. The latter frequency of $M$. pneumoniae is generally not seen even in epidemics of the same bacterial infection. The reliance on IgM serology alone could explain a high false-positive rate. Some patients had two 
Table 1 General technical problems potentially associated with the diagnosis of coinfections

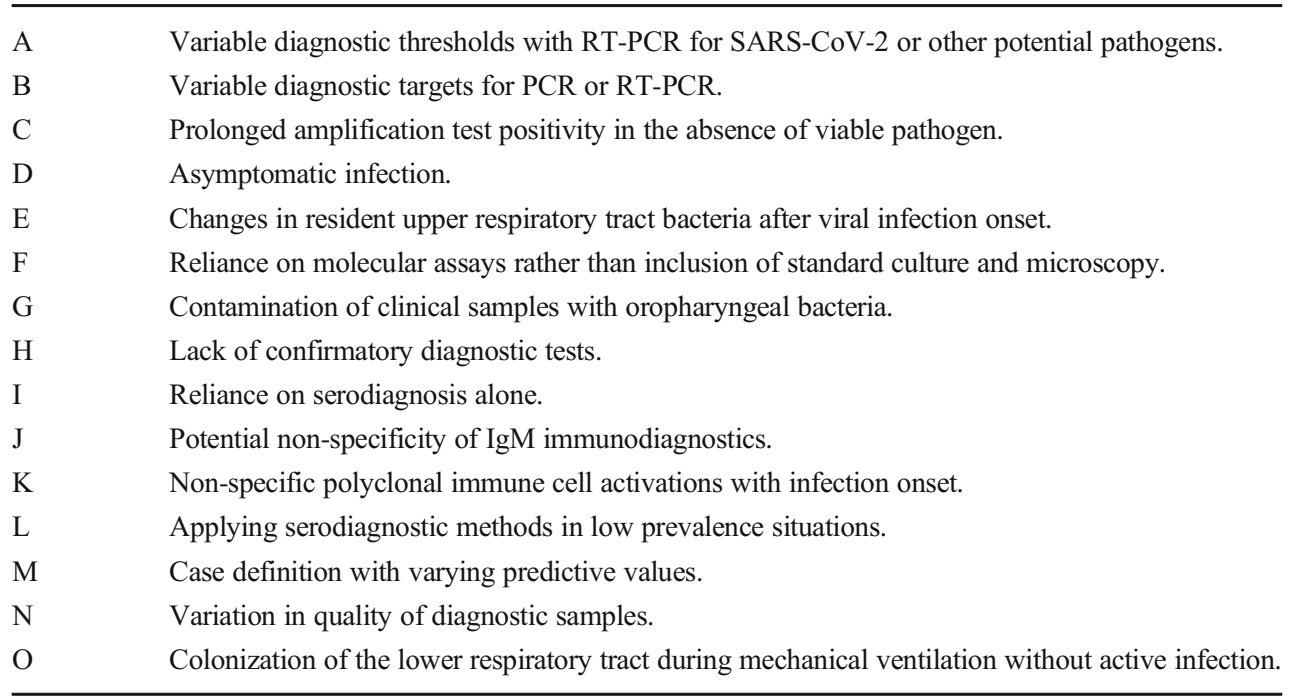

co-pathogen detections, and one patient was said to have SARS-CoV-2 along with four co-pathogens. The lack of an $\mathrm{IgG}$ response to co-exist in some reports, even early, is unlikely since IgG reactivity occurs alongside or very shortly after IgM detection for $M$. pneumoniae. In one citation and examining paired sera over 15 days, the patient's IgM response disappeared as did the IgG response [17]. Anti-M. pneumoniae IgM responses arise usually within 7 days or more after infection onset, and the subsequent IgG responses along with IgM are likely to persist for weeks to months thereafter [23]. One must realize that $M$. pneumoniae serology could be either non-specific or that $M$. pneumoniae infection occurred much earlier than COVID-19, and that the serological response was yet lingering.

Atypical pneumonia presentations from $M$. pneumoniae can confuse with clinical diagnoses of COVID-19. Conventional serological diagnosis for M. pneumoniae can be fraught with difficulty unless confirmed with immunoblotting $[23,24]$. Non-specific polyclonal activations for rheumatoid factor or other antibodies can also arise [25]. Rheumatoid factor is a well-recognized potential confounder for IgM serology. The phenomenon of potential overdiagnosis is illustrated by the manner in which cumulative data can be skewed by unrecognized diagnostic difficulties for M. pneumoniae [26]. These features would generally parallel expectations and concerns for other putative co-infections.

Of note in the above regards, Fujita illustrates how $M$. pneumoniae, like some respiratory viruses, has diminished in prevalence during the time when enhanced precautions are being observed for SARS-CoV-2 [27]. The high frequency of $M$. pneumoniae infection in the midst of other virus infections has been proposed both recently and in the past many times [28].

\section{Lessons From Comparative Human Coronavirology and Co-Infection}

Prior to SARS-CoV-2, there were many population studies throughout the world that detailed the frequency of endemic respiratory human coronaviruses and their associations with co-infection [2]. Several commonalities emerged. In a context where these endemic coronaviruses comprised a considerable minority of causative agents for community-acquired respiratory infections, the frequency of co-infection was quite variable but at times as frequent as three-fourths of the entirety. Multiple co-viral pathogens were sometimes detected, and several reports documented presence of more than one coexisting coronavirus in a clinical sample. Common viral copathogens included respiratory syncytial virus, rhinovirus, influenza, and adenovirus, and there was no bias for any one of four endemic respiratory coronaviruses being associated with co-infection.

The finding of the above coronaviruses in co-infection did not consistently associate with worse outcome, type of illness, or age groups with some exceptions [2, 29]. Few studies validated co-infections with secondary confirmatory diagnostics which raises concern for specificity $[2,30]$. Of equal importance, some studies found equal frequency of viral coinfections regardless of whether the respiratory coronavirus detection occurred for ill patients or asymptomatic controls $[9,31]$. At least in this context, the finding of co-detections raises concern of whether the observations are truly indicative of co-infections even if such chance observations are to be anticipated. These issues are only more so suspect given that the majority of reports used genome amplification technologies only for coronavirus and other virus detections.

There are comparatively few reports of co-infections among patients who suffered Severe Acute Respiratory 
Infection (SARS) or Middle East Respiratory Syndrome (MERS). Lee and colleagues [32] found a high rate $(20 \%)$ of co-incident human metapneumovirus infections among SARS patients. SARS illnesses did not seem to be complicated by the second virus. No confirmatory studies were performed. The finding of co-pathogens with MERS is complicated by the lack of finding MERS among large groups of patients in many studies [33-35]. A small study of 47 MERS infections did not find co-viral pathogens [36]. Co-infections of MERS$\mathrm{CoV}$ with tuberculosis and influenza have only emerged with few patients [37, 38].

\section{The COVID-19 Experience}

\section{Co-Detection of SARS-CoV-2 and Influenza Virus}

An animal model of SARS-CoV-2 infection has been used to study co-infection with an influenza H1N1 variant [39]. Coinfection or sequential infection was associated with an accentuation of lung pathology.

Several reports of co-infection with influenza were obtained after the first wave of COVID-19 in early 2020 [19, 40-46]. Four reports from China detailed a high frequency of influenza co-infection, especially for influenza A variants $[19,42,43,46]$. The finding of nearly one-half of their patients having dual infection raises some concern for diagnostic specificity. These studies utilized IgM immunofluorescence or EIA serology for influenza diagnosis without secondary tests of confirmation. Other analyses from some of these studies suggested that certain co-infections could have correlates with poor overall outcomes. Yet another publication determined a very high frequency of co-infection among patients who deceased [41]. Using genome amplification diagnostic methods, both influenza and other respiratory virus co-infections were considerably frequent $(\sim 47 \%)$. The study also highlighted co-infections among children where the second virus was solely human metapneumovirus. This study too raises concern about the specificity of laboratory viral diagnostics when a single method for determination is utilized. As has been experienced globally, control measures for COVID-19 have necessarily led to a considerable decline in other virus infections including influenza [45, 47, 48]. Yu et al. [44] further detail the possible effect of antiviral therapy to mitigate dual infections where influenza is seemingly a co-factor. The frequency for finding influenza has been exceedingly low in some centers [47, 49-51]. Further reduction may be linked to COVID-19 public health precautions [27]. 


\section{Co-Detection of SARS-CoV-2 and Other Respiratory Viruses}

Table 3 illustrates the spectrum of viral co-detections that have been found among COVID-19 patients. Several themes emerge. Generally, the co-infection frequency with other viral pathogens is low [47, 58, 61, 63, 67-69, 74-78]. One systematic review identified a relatively low incidence of viral coinfection $(\sim 3 \%)$ [26]. The large multicenter cohort study from MI, USA found only a $0.5 \%$ incidence of viral co-infection when samples were obtained in early presentations [76]. Covirus patterns of laboratory diagnostics do not in themselves associate with COVID-19 [55, 62]. Among the more common seemingly co-virus pathogens are rhinovirus/enterovirus, respiratory syncytial virus, and influenza viruses. Most of these studies are observational and vary in the spectrum of other viruses that could be detected. Apart from SARS-CoV-2, other coronaviruses have been co-detected, but not any one has a predilection for such association $[44,47,52,54,56,62$, 71-73, 79]. Some co-infections have included more than one other virus $[18,56,57,62,71]$. Among deceased patients, there is a greater frequency of co-infections, especially influenza, in early reports $[41,42]$. The frequency of co-finding human metapneumovirus did not change before and after the pandemic onset [80]. Most putative co-infections are mild in presentation and convalescence [52]. Nevertheless, some reports suggest that co-infection may be associated with a higher rate of intensive care requirement or prolonged hospital stay $[53,66,78]$. Viral co-infection does not seem to be correlated with age [54]. The citation of SARS-CoV-2 and MERS-CoV co-infections must be carefully considered for diagnostic thresholds and confirmatory testing [79].

Despite the above, it has been noted by many that a general reduction in the prevalence of other seasonal respiratory viruses has been evident and has been ascribed to prevention measures otherwise used for COVID-19 [81, 82].

\section{Co-Detection of SARS-CoV-2 with Selected Non-Viral Infections and Chronic Viral Infections}

There are many anecdotes of co-infection that include a very broad array of human pathogens, and there are yet likely many more examples to come if not only for the co-incidence that they should occur. Given the global reality of the pandemic, and regardless of seasonality, co-infections are seen among patients with unique non-viral infections. Reports have been made of SARS-CoV-2 infection complicating parasitic diseases [83-85]. Intestinal parasite co-infection however was seemingly associated with less severe COVID-19 [86]. Yet other reports illustrate virus infection either complicating or giving way to various fungal infections $[87,88]$. With the use of multiple antibacterial treatments, corticosteroids, or immunomodulating agents otherwise, it is not surprising to see an association of COVID-19 with opportunistic fungi such as yeast and Aspergillus spp. among others [88-92]. The importance of appropriate case definitions for infection is underscored $[91,93]$. Unique co-infections with atypical or chronic bacterial infections (in addition to M. pneumoniae as previously discussed) have also been cited [94-100]. Among the latter, the finding of $20 \%$ of adults having concomitant Bordetella pertussis infections must raise again concern with the applicability of diagnostic methods [100]. For Clostridiodes difficile, associated risk factors for co-infection including antibiotic use are not surprising, and there is no seemingly unique propensity with COVID-19 [99].

There are citations of unique co-infections of SARS-CoV-2 with other systemic viral illnesses [101-111]. Such coinfection was particularly of interest in the context of chronic HIV infection where persistent immunocompromise or enhanced infection susceptibility otherwise might allow for either of the infections to be more severe than not [104-106, 112]. HIV-1 co-infection is associated with altered $T$ cell responses to SARS-CoV-2, and this phenomenon was also observed for Mycobacterium tuberculosis co-infections [110]. Others have found some contradictory evidence [113]. These studies do not, however, indicate that either of the latter infections markedly affects the other. For chronic hepatitis B patients, early reports suggest that COVID-19 increases the potential for complicating outcomes [107, 108]. Others have suggested that chronic hepatitis B did not predispose patients to a more severe outcome [109]. In the context of chronic hepatitis $\mathrm{C}$ infection, COVID-19 did not appear to occur more often nor was it associated with overly severe outcomes [114]. Reactivation of systemic herpesvirus group infections should be reconsidered when severely ill COVID-19 patients are cared for [111].

\section{The Impact of COVID-19 on Associated Post-Onset Bacterial Infections}

Virus upper respiratory infections are commonly associated with a quantitative increase in various normal commensal bacteria. The latter phenomenon increases the odds of secondary bacterial infections of the middle ears, sinuses, and respiratory tract in the milieu of existing viral-induced inflammation. The occurrence of secondary infections is generally anticipated, albeit the frequency of the same could be variable. Such perturbation is also evident during COVID-19 as shown through molecular epidemiological studies of the upper respiratory microbiome [115-117]. Admission to healthcare centers carries with it the opportunity for nosocomial infections. Again, these should occur to some degree given the potential severity and prolonged hospital stay for some COVID-19 infections. Respiratory and bloodstream infections are among the more common nosocomial infections [118]. Empiric, potent, or prolonged antibiotic therapy increases risk for 


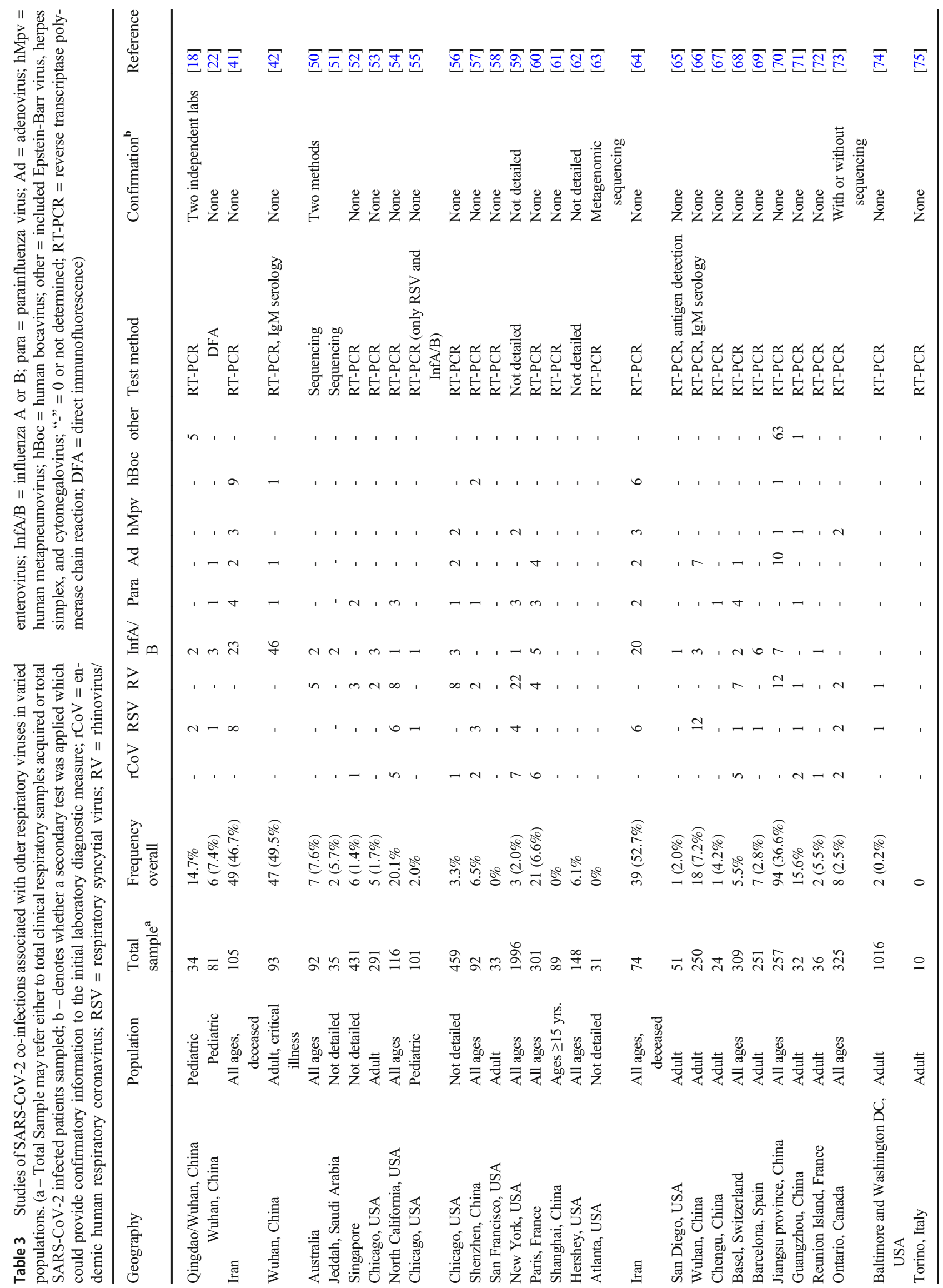


nosocomial infection. In addition, the COVID-19 context has been significantly associated with increasing antibiotic use [119-121]. The presence of a potentially complex infection along with the use of either steroids or immunomodulatory treatments otherwise increases the potential for secondary bacterial infections. The respiratory microbiome is anticipated to change during the course of infection [122]. More severe illnesses will increase the propensity to use invasive treatment and monitoring if not mechanical ventilation and hence again increase the tendency for secondary bacterial infections. Patient co-morbidities will also be anticipated to affect secondary infection rates. Perez et al. [123] found that reluctant or inadvertent relaxation of infection control policies during intense COVID-19 activity might account for such nosocomial infections. Others found evidence of relapsing Gram-negative nosocomial infections as pandemic disease emerged in the context of focused infection control measures [124].

The detection of bacterial co-pathogens does not ensure cause-and-effect relationship. As for co-viral infections, codetection does not consistently imply co-infection. Some patients may have carriage of high numbers of potentially pathogenic bacteria in either the respiratory tract or at the endotracheal site during intubation without infection. The potential for such ambiguity is illustrated by several studies in which molecular amplification studies have been used for secondary bacterial diagnosis [100, 125-129]. Although there is a correlation of amplification $\mathrm{Ct}$ values with bacterial load, even such quantitative assessment does not necessarily imply infection. Furthermore, such detection does not guarantee live bacterium analogous to the issue of viable versus non-viable virus with similar technology. Kolenda et al. [129] tactfully address this issue with corroborative evidence. They found that up to $60 \%$ of bacteria found by amplification assay could not be corroborated with culture results. A majority of such determinations were of usual normal oral bacteria and of lesser numbers. What is lost in these approaches is the art of correlation between microscopic smear examination and semi-quantitative bacteriology which often can give strong clues to the validity of data application [130]. Using microscopic smear examination of good quality respiratory samples may also allow the finding of a predominance of white blood cells which are mononuclear in morphology and which may further the likelihood of virus or atypical agent versus usual cultivable bacteria. The potential lost art of microscopy in this context cannot be underestimated.

The COVID-19 experience on this theme is considerable to date. Empiric antibiotic use is common among these patients $[76,119-121,131]$. The frequency of such use may decline with experience [76]. Macrolide and beta-lactam antimicrobial use dominate in this context [121]. There is a low incidence of secondary bacterial infections in many studies [74, 76, 120, 121, 131-134]. The lower incidence is most common among the very early phases of infection as would be anticipated [76,
134]. The type of proposed co-pathogen changes during the course of COVID-19 [49, 76, 118, 128, 134-140]. Common respiratory bacteria more often cause infection in early stages of the illness [75, 125, 129, 133, 141-143]. Nosocomial infections can be common as the viral illness progresses albeit the institutional rate is quite variable $[49,118,119,123,131$, 135-140, 144-147]. Much of the latter includes opportunistic Gram-negative bacilli $[49,100,118,119,123,124,126,137$, $138,140,144,145,147,148]$. Fungal infections, especially with Candida spp., occur with worse disease and increased hospital stay $[118,126,135,136,139,144,145,147$, 149-151]. The latter may occur in up to $14 \%$ of such patients $[134,138,139]$. As anticipated, antimicrobial therapy and steroid use can pose as risk factors for such invasive fungal infections [147, 151].

Some have found that co-detections found early are not associated with increased morbidity or mortality [152]. Payson et al. [153] determined that very young children with COVID-19 were less likely to suffer from serious bacterial infections compared to a control group with other virus infections. High rates of co-infections nevertheless are generally associated with worse disease and with mortality among other populations $[118,123,126,132,137,138,141,142$, 154-158]. Bacterial co-infections have an increased frequency as patient age advances $[125,155]$. The greater the presence of patient co-morbidities, the more frequent the finding of co-incident infections [125, 135]. Gram-negative bacillus infections are associated with increased hospital stay and severe COVID-19 [118, 140, 157-160]. They more often arise either in the respiratory tract, with intravenous access devices, or with genitourinary foci $[145,155,156,158,160]$. Bacteremias tend to be less common but are more likely to be seen with intensive care patients [77, 145, 156, 159, 161]. A low rate of COVID-19-associated community-acquired bacteremia has been reported despite the high frequency of COVID-19-related deaths [162]. Cusumano et al. [163] particularly find that Staphylococcus aureus bacteremia may be an important predictor of worse outcome. There is an increasing antibiotic resistance profile with co-infection [122, 123, $127,135,137,140,142,144,146,157,159,160,163,164]$. For example, some American centers have been particularly inundated with multi-resistant coliforms $[135,157]$. Hughes et al. [49] found that co-infection rates do not differ substantially when comparing patients with COVID-19 to those with purely influenza virus. The phenomenon of COVID-19 coinfection with bacteria that are existing with or evolving hypervirulent traits is in its infancy for research [148]. Changes to usual hospital infection control in times of complicating patient surge must be considered in the context of increasing nosocomial infection [159]. Imperative in the control of both COVID-19 and associated nosocomial infections is the due regard that must be given to appropriate environmental containment strategies $[6,165]$. 


\section{Conclusion}

There is generally a low rate of new bonafide viral coinfections in early COVID-19 as currently appreciated. Reports of high co-infection rates must be tempered by limitations in current diagnostic methods. Inevitably, COVID-19 will occur superimposed on existing infections, and by virtue of the frequency of COVID-19, other superimposed infections will occur during a SARS-CoV-2 infection. In the context of increasingly severe COVID-19, opportunistic and nosocomial infections will occur due to the prolonged and intense nature of some diseases and the common use of both antibiotics and immunomodulatory treatments. Further data accumulation is justified, and further insight into co-infections with COVID19 will provide better guidance for effective antimicrobial therapy whether for SARS-CoV-2 or bonafide co-infections.

The general precautions used for COVID-19 prevention have clearly reduced the frequency of other concurrent and seasonal viral respiratory infections. As vaccines are implemented and control strategies are proportionately relaxed, the general background prevalence of seasonal respiratory viruses will return at which time it may be anticipated that co-infections with SARS-CoV-2 will increase, and this topic will become of increasing relevance and complexity.

Code Availability Not applicable.

Author Contribution There is one author, and there are no government, industry, or Trust connections.

Data availability Not required.

\section{Declarations}

Ethics Approval Ethics approval is not required for this review.

Consent to Participate Consent is not required for the review.

Consent for Publication There is only one author.

Conflict of Interest The author declares no competing interests.

\section{References}

1. Thuy-Boun PS, Mehta S, Gruening B, McGowan T, Nguyen A, Rajczewski AT, et al. Metaproteomics analysis of SARS-CoV-2infected patient samples reveals presence of potential coinfecting microorganisms. J Proteome Res. 2021. https://doi.org/10.1021/ acs.jproteome.0c00822.

2. Cimolai N. Complicating infections associated with common endemic human respiratory coronaviruses. Health Security. 2020;19: 195-208. https://doi.org/10.1089/hs.2020.0067.
3. Cimolai N. Features of enteric disease from human coronaviruses: implications for COVID-19. J Med Virol. 2020. https://doi.org/10. 1002/jmv.26066.

4. Cimolai N. Not all viral culture approaches are equal. Clin Infect Dis. 2020:ciaa1632. https://doi.org/10.1093/cid/ciaa1632.

5. Li Q, Zheng X-S, Shen X-R, Si H-R, Wang X, Wang Q, et al. Prolonged shedding of severe acute respiratory syndrome coronavirus 2 in patients with COVID-19. Emerg Microbes Infect. Nov. 2020;16:1-28. https://doi.org/10.1080/22221751.2020. 1852058.

6. Cimolai N. Environmental and decontamination issues for human coronaviruses and their potential surrogates. J Med Virol. 2020. https://doi.org/10.1002/jmv.26170.

7. de Koff EM, van Houten MA, Sanders EAM, Bogaert D. Severity of respiratory infections with seasonal coronavirus is associated with viral and bacterial coinfections. Pediatr Infect Dis J. 2020 https://doi.org/10.1097/INF.0000000000002940.

8. Fairchok MP, Martin ET, Chambers S, Kuypers J, Behrens M, Braun LE, et al. Epidemiology of viral respiratory tract infections in a prospective cohort of infants and toddlers attending daycare. $\mathrm{J}$ Clin Virol. 2010;49(1):16-20.

9. Heimdal I, Moe N, Krokstad S, Christensen A, Skanke LH, Nordbø SA, et al. Human coronavirus in hospitalized children with respiratory tract infections: a 9-year population-based study from Norway. J Infect Dis. 2019;219(8):1198-206.

10. van der Hoek L, Sure K, Ihorst G, Stang A, Pyrc K, Jebbink MF, et al. Croup is associated with the novel coronavirus NL63. PLoS Med. 2005;2(8):e240.

11. Jevšnik M, Uršič T, Zigon N, Lusa L, Krivec U, Petrovec M. Coronavirus infections in hospitalized pediatric patients with acute respiratory tract disease. BMC Infect Dis. 2012;12:365.

12. Cimolai N, Wensley D, Seear M, Thomas ET. Mycoplasma pneumoniae as a cofactor in severe respiratory infections. Clin Infect Dis. 1995;21(5):1182-5.

13. Amin D, McKitish K, Shah PS. Association of mortality and recent Mycoplasma pneumoniae infection in COVID-19 patients. J Med Virol. 2020. https://doi.org/10.1002/jmv.26467.

14. Gayam V, Konala VM, Naramala S, Reddy Garlapati P, Merghani MA, Regmi N, et al. Presenting characteristics, comorbidities, and outcomes of patients coinfected with COVID-19 and Mycoplasma pneumoniae in the USA. J Med Virol. https://doi.org/10.1002/ jmv.26026.

15. Zha L, Shen J, Tefsen B, Wang Y, Lu W, Xu Q. Clinical features and outcomes of adult COVID-19 patients co-infected with Mycoplasma pneumoniae. J Infect. 2020;81(3):e12-5.

16. Plebani A, Meini A, Cattalini M, Lougaris V, Bugatti A, Caccuri F, et al. Mycoplasma infection may complicate the clinical course of SARS-CoV-2 associated Kawasaki-like disease in children. Clin Immunol. 2020;221:108613.

17. Huang AC-C, Huang C-G, Yang C-T, Hu H-C. Concomitant infection with COVID-19 and Mycoplasma pneumoniae. Biomed J. https://doi.org/10.1016/j.bj.2020.07.002.

18. Wu Q, Xing Y, Shi L, Li W, Gao Y, Pan Y, et al. Coinfection and other clinical characteristics of COVID-19 in children. Pediatrics. 2020;146(1):e20200961.

19. Wei L, Gao X, Chen S, Zeng W, Wu J, Lin X, et al. Clinical characteristics and outcomes of childbearing-age women with COVID-19 in Wuhan: retrospective, single-center study. J Med Internet Res. 2020;22(8):e19642.

20. Gao Z-A, Bao L-B, Chen X-J, Xu Y. Fourty-nine years old woman co-infected with SARS-CoV-2 and Mycoplasma: a case report. World J Clin Cases. 2020;8(23):6080-5.

21. Choubey A, Sagar D, Cawley P, Miller K. Retrospective review analysis of COVID-19 patients co-infected with Mycoplasma pneumoniae. Lung India. 2021;38(Supp):S22-6. 
22. Li Y, Wang H, Wang F, Lu X, Du H, Xu J, et al. Co-infections of SARS-CoV-2 with multiple common respiratory pathogens in infected children: a retrospective study. Medicine. 2021;100(11): e24315.

23. Cimolai N. Serodiagnosis of the infectious diseases: Mycoplasma pneumoniae. Norwell: Kluwer Academic Publishers; 1999.

24. Cimolai N, Cheong AC. IgM anti-P1 immunoblotting. A standard for the rapid serologic diagnosis of Mycoplasma pneumoniae infection in pediatric care. Chest. 1992;102(2):477-81.

25. Cimolai N, Cheong AC. Anti-smooth muscle antibody in clinical human and experimental animal Mycoplasma pneumoniae infection. J Appl Microbiol. 1997;82(5):625-30.

26. Lansbury L, Lim B, Baskaran V, Lim WS. Co-infections in people with COVID-19: a systematic review and meta-analysis. J Infect. 2020;81(2):266-75.

27. Fujita J. Mycoplasma pneumoniae pneumonia and respiratory syncytial virus infection in Japan during the severe acute respiratory syndrome coronavirus 2 pandemic. Respir Investig. 2020: S2212-5345(20)30163-5. https://doi.org/10.1016/j.resinv.2020. 11.002 .

28. Li J, Song C-L, Wang T, Ye Y-L, Du J-R, Li S-H, et al. Etiological and epidemiological characteristics of severe acute respiratory infection caused by multiple viruses and Mycoplasma pneumoniae in adult patients in Jinshan, Shanghai: a pilot hospital-based study. PLoS One. 2021;16(3):e0248750.

29. Loevinsohn G, Hardick J, Sinywinmaanzi P, Penstermacher KZJ, Shaw-Saliba K, Monze M, et al. Respiratory pathogen diversity and co-infections in rural Zambia. Int J Infect Dis. 2020:S12019712(20)32258-X. https://doi.org/10.1016/j.ijid.2020.10.054.

30. Jevšnik M, Steyer A, Pokorn M, Mrvič T, Grosek S, Strle F, et al. The role of human coronaviruses in children hospitalized for acute bronchiolitis, acute gastroenteritis, and febrile seizures: a 2-year prospective study. PLoS One. 2016;11(5):e0155555.

31. Berkley JA, Munywoki P, Ngama M, Kazungu S, Abwao J, Bett A, et al. Viral etiology of severe pneumonia among Kenyan infants and children. JAMA. 2010;303(20):2051-7.

32. Lee N, Chan PKS, Yu IT, Tsoi KK, Lui G, Sung JJY, et al. Cocirculation of human metapneumovirus and SARS-associated coronavirus during a major nosocomial SARS outbreak in Hong Kong. J Clin Virol. 2007;40(4):333-7.

33. Al-Tawfiq JA, Benkouiten S, Memish ZA. A systematic review of emerging respiratory viruses at the Hajj and possible coinfection with Streptococcus pneumoniae. Travel Med Infect Dis. 2018;23: 6-13.

34. Abdulhaq AA, Basode VK, Hashem AM, Alshrari AS, Badroon NA, Hassan AM, et al. Patterns of human respiratory viruses and lack of MERS-coronavirus in patients with acute upper respiratory tract infections in southwestern province of Saudi Arabia. Adv Virol. 2017;4247853.

35. Hashem AM, Al-Subhi TL, Badroon NA, Hassan AM, Hussein $\mathrm{M}$, Bajrai L, et al. MERS-CoV, influenza and other respiratory viruses among symptomatic pilgrims during 2014 Hajj season. J Med Virol. 2019;91(6):911-7.

36. Assiri A, Al-Tawfiq JA, Al-Rabeeah AA, Al-Rabiah FA, AlHajjar S, Al-Barrak A, et al. Epidemiological, demographic, and clinical characteristics of 47 cases of Middle East respiratory syndrome coronavirus disease from Saudi Arabia: a descriptive study. Lancet Infect Dis. 2013;13:752-61.

37. Alfaraj SH, Al-Tawfiq JA, Altuwaijri TA, Memish ZA. Middle East Respiratory Syndrome coronavirus and pulmonary tuberculosis coinfection: implications for infection control. Intervirology. 2017:60(1-2):53-5.

38. Alfaraj SH, Al-Tawfiq JA, Alzahrani NA, Altwaijri TA, Memish ZA. The impact of co-infection of influenza A virus on the severity of Middle East Respiratory Syndrome coronavirus. J Infect. 2017;74(5):521-3
39. Zhang AJ, Lee AC-Y, Chan JF-W, Liu F, Li C, Chen Y, et al. Coinfection by severe acute respiratory syndrome coronavirus 2 and influenza (H1N1)pdm09 virus enhances the severity of pneumonia in golden Syrian hamsters. Clin Infect Dis. 2020:ciaa1747. https://doi.org/10.1093/cid/ciaa1747.

40. Miatech JL, Tarte NN, Katragadda S, Polman J, Robichaux SB. A case series of coinfection with SARS-CoV-2 and influenza virus in Louisiana. Respir Med Case Rep. 2020;31:101214.

41. Hashemi SA, Safamanesh S, Ghasemzadeh-Moghaddam H, Ghafouri M, Azimian A. High prevalence of SARS-CoV-2 and influenza A virus (H1N1) coinfection in dead patients in Northeastern Iran. J Med Virol. 2020;93:1008-12. https://doi. org/10.1002/jmv.26364.

42. Ma S, Lai X, Chen Z, Tu S, Qin K. Clinical characteristics of critically ill patients co-infected with SARS-CoV-2 and the influenza virus in Wuhan, China. Int J Infect Dis. 2020;96:683-7.

43. Yue H, Zhang M, Xing L, Wang K, Rao X, Liu H, et al. The epidemiology and clinical characteristics of co-infection of SARS-CoV-2 and influenza viruses in patients during COVID19 outbreak. J Med Virol. 2020. https://doi.org/10.1002/jmv. 26163.

44. Yu C, Zhang Z, Guo Y, Shi J, Pei G, Yao Y, et al. Lopinavirritonavir is associated with pneumonia resolution in COVID-19 patients with influenza coinfection: a retrospective matched-pair cohort study. J Med Virol. https://doi.org/10.1002/jmv.26260.

45. Kuo S-C, Shih S-M, Chien L-H, Hsiung CA. Collateral benefit of COVID-19 control measures on influenza activity. Taiwan. Emerg Infect Dis. 2020;26(8):1928-30.

46. Cheng Y, Ma J, Wang H, Wang X, Hu Z, Li H, et al. Co-infection of influenza A virus and SARS-CoV-2: a retrospective cohort study. J Med Virol. 2021 Jan 21;93:2947-54. https://doi.org/10. 1002/jmv.26817.

47. Boschi C, Hong VT, Giraud-Gatineau A, Ninove L, Lagier J-C, La Scola P, et al. Co-infections with SARS-CoV-2 and other respiratory viruses in southeastern France: a matter of sampling time. J Med Virol. https://doi.org/10.1002/jmv.26692.

48. Parry MF, Shah AK, Sestovic M, Salter S. Precipitous fall in common respiratory viral infections during COVID-19. Open Forum Infect Dis. 2020;7(11):ofaa511.

49. Hughes S, Troise O, Mughal N, Moore SP. Bacterial and fungal coinfection among hospitalized patients with COVID-19: a retrospective cohort study in a UK secondary-care setting. Clin Microbiol Infect. 2020;26(10):1395-9.

50. Kim KW, Deveson IW, Pang CNI, Yeang M, Naing Z, Adikari T, et al. Respiratory viral co-infections among SARS-CoV-2 cases confirmed by virome capture sequencing. Sci Rep. 2021;11(1): 3934.

51. Bi C, Ramos-Mandujano G, Tian Y, Hala S, Xu J, Mfarrej S, et al. Simultaneous detection and mutation surveillance of SARS-CoV2 and co-infections of multiple respiratory viruses by rapid fielddeployable sequencing. Med (N Y). 2021. https://doi.org/10.1016/ j.medj.2021.03.015

52. Wee LE, Ko KKK, Ho WQ, Teck Cheng Kwek G, Tan TT, Wijaya L. Community-acquired viral respiratory infections amongst hospitalized inpatients during a COVID-19 outbreak in Singapore: co-infection and clinical outcomes. J Clin Virol. 2020;128:104436. https://doi.org/10.1016/m.jcv.2020.104436.

53. Lehmann CJ, Pho MT, Pitrak D, Ridgway JP, Pettit NN. Community acquired co-infection in COVID-19: a retrospective observational experience. Clin Infect Dis. 2020:ciaa902. https:// doi.org/10.1093/cid/ciaa902.

54. Kim D, Quinn J, Pinsky B, Shah NH, Brown I. Rates of coinfection between SARS-CoV-2 and other respiratory pathogens. JAMA. 2020;323(20):2085-6.

55. Zhang DD, Acree ME, Ridgway JP, Shah N, Hazra A, Ravichandran $\mathrm{U}$, et al. Characterizing coinfection in children with 
COVID-19: a dual center retrospective analysis. Infect Control Hosp Epidemiol. 2020 Sep;23:1-3. https://doi.org/10.1017/ice. 2020.1221

56. Hazra A, Collison M, Pisano J, Kumar M, Oehler C, Ridgway JP. Coinfections with SARS-CoV-2 and other respiratory pathogens. Infect Control Hosp Epidemiol. 2020;41(10):1228-36.

57. Lin D, Liu L, Zhang M, Hu Y, Yang Q, Guo J, et al. Co-infections of SARS-CoV-2 with multiple common respiratory pathogens in infected patients. Sci China Life Sci. 2020;63(4):606-9.

58. Shah SJ, Barish PN, Prasad PA, Kistler AL, Neff N, Kamm J, et al. Clinical features, diagnostics, and outcomes of patients presenting with acute respiratory illness: a comparison of patients with and without COVID-19. Lancet. 2020;27:100518. https://doi.org/10. 1016/j.eclinm.2020.100518.

59. Richardson S, Hirsch JS, Narasimhan M, Crawford JM, McGinn T, Davidson KW, et al. Presenting characteristics, comorbidities, and outcomes among 5700 patients hospitalized with COVID-19 in the New York City area. JAMA. 2020;323(20):2052-9.

60. Burrel S, Hausfater P, Dres M, Pourcher V, Luyt C-E, Teyssou E, et al. Co-infection of SARS-CoV-2 with other respiratory viruses and performance of lower respiratory tract samples for the diagnosis of COVID-19. Int J Infect Dis. 2020:S1201-9712(20)32244X. https://doi.org/10.1016/j.ijid.2020.10.040.

61. Song W, Jia X, Zhang X, Ling Y, Yi Z. Co-infection in COVID19, a cohort study. J Infect. 2020:S0163-4453(20)30648-4. https:// doi.org/10.1016/j.inf.2020.10.006.

62. Gopaul R, Davis J, Gangai L, Goetz L. Practical diagnostic accuracy of nasopharyngeal swab testing for novel coronavirus disease 2019 (COVID-19). West J Emerg Med. 2020;21:1-4. https://doi. org/10.5811/westjem.2020.8.48420.

63. Babiker A, Bradley HL, Stittleburg VD, Ingersoll JM, Key A, Kraft CS, et al. Metagenomic sequencing to detect respiratory viruses in persons under investigation for COVID-19. J Clin Microbiol. 2020:JCM.02142-20 10.1128/JCM.02142-20.

64. Hashemi S-A, Safamanesh S, Ghasemzadeh-Moghaddam H, Ghafouri M, Mohajerzadeh-Heydari M-S, Namdar-Ahmadabad $\mathrm{H}$, et al. Report of death in children with SARS-CoV-2 and human metapneumovirus (hMPV) coinfection: is hMPV the trigger? J Med Virol. 2020. https://doi.org/10.1002/jmv.26401.

65. Castillo EM, Coyne CJ, Brennan JJ, Tomaszewski CA. Rates of coinfection with other respiratory pathogens in patients positive for coronavirus disease 2019 (COVID-19). J Am Coll Emerg Physicians Open. 2020;1(4):592-6.

66. Ma L, Wang W, Le Grange JM, Wang X, Du S, Li C, et al. Coinfection of SARS-CoV-2 and other respiratory pathogens. Infect Drug Resist. 2020;13:3045-53.

67. Si Y, Zhao Z, Chen R, Zhong H, Liu T, Wang M, et al. Epidemiological surveillance of common respiratory viruses in patients with suspected COVID-19 in southwest China. BMC Infect Dis. 2020;20(1):688.

68. Leuzinger K, Roloff T, Gosert R, Sogaard K, Naegele K, Rentsch $\mathrm{K}$, et al. Epidemiology of severe acute respiratory syndrome coronavirus 2 emergence amidst community-acquired respiratory viruses. J Infect Dis. 2020;222(8):1270-9.

69. Garcia-Vidal C, Sanjuan G, Moreno-Garcia E, Puerta-Alcalde P, Garcia-Pouton N, Chumbita M, et al. Incidence of co-infections and superinfections in hospitalized patients with COVID-19: a retrospective cohort study. Clin Microbiol Infect. 2020;S1198743X(20)30450-X. https://doi.org/10.1016/j.cmi.2020.07.041.

70. Zhu X, Ge Y, Wu T, Zhao K, Chen Y, Wu B, et al. Co-infection with respiratory pathogens among COVID-2019 cases. Virus Res. 2020;285:198005. https://doi.org/10.1016/j.virusres.2020. 198005.

71. Li Z, Z-m C, Chen L-D, Zhan Y-Q, Li S-Q, Cheng J, et al. Coinfection with SARS-CoV-2 and other respiratory pathogens in patients with COVID-19 in Guangzhou, China. J Med Virol. 2020;92:2381-3.

72. Allou N, Larsen K, Dubernet A, Traversier N, Masse L, Foch E, et al. Co-infection in patients with hypoxemic pneumonia due to COVID-19 in Reunion Island. Medicine. 2021;100(4):e24524.

73. Peci A, Tran V, Guthrie JL, Nelson P, Schwartz KL, Eshaghi AR, et al. Prevalence of co-infections with respiratory viruses in individuals investigated for SARS-CoV-2 in Ontario, Canada. Viruses. 2021;13(1):E120.

74. Karaba SM, Jone G, Helsel T, Smith CL, Avery R, Dzintars K, et al. Prevalence of co-infection at the time of hospital admission in COVID-19 patients, a multicenter study. Open Forum Infect Dis. 2020;8(1):ofaa578.

75. Calcagno A, Ghisetti V, Burdino E, Trunfio M, Allice T, Boglione $\mathrm{L}$, et al. Coinfection with other respiratory pathogens in COVID19 patients. Clin Microbiol Infect. 2020;S1 198-743X(20)304948. https://doi.org/10.1016/j.cmi.2020.08.012.

76. Vaughn VM, Gandhi T, Petty LA, Patel PK, Prescott HC, Malani AN, et al. Empiric antibacterial therapy and community-onset bacterial co-infection in patients hospitalized with COVID-19: a multi-hospital cohort study. Clin Infect Dis. 2020;ciaa1239. https://doi.org/10.1093/cid/ciaa1239.

77. Sepulveda J, Westblade LF, Whittier S, Satlin MJ, Greendyke WG, Aaron JG, et al. Bacteremia and blood culture utilization during COVID-19 surge in New York City. J Clin Microbiol. 2020;58(8):e00875-20.

78. Schirmer P, Lucero-Obusan C, Sharma A, Sohoni P, Oda G, Holodny M. Respiratory co-infections with COVID-19 in the Veterans Health Administration, 2020. Diagn Microbiol Infect Dis. 2021;100(1):115312.

79. Elhazmi A, Al-Tawfiq JA, Sallam H, Al-Omari A, Alhumaid S, Mady A, et al. Severe respiratory syndrome coronavirus 2 (SARSCoV-2) and Middle East Respiratory Syndrome Coronavirus (MERS-CoV) coinfection: a unique case series. Travel Med Infect Dis. 2021;13:102026. https://doi.org/10.1016/j.tmaid. 2021.102026.

80. Jongbloed M, Leijte WT, Linssen CFM, van den Hoogen BG, van Gorp ECM, de Kruif MD. Clinical impact of human metapneumovirus infections before and during the COVID-19 pandemic. Infect Dis. 2021;20:1-10. https://doi.org/10.1080/ 23744235.2021.1887510.

81. Tang JW, Bialasiewicz S, Dwyer DE, Dilcher M, Tellier R, Taylor $\mathrm{J}$, et al. Where have all the viruses gone? Disappearance of seasonal respiratory viruses during the COVID-19 pandemic. J Med Virol. 2021. https://doi.org/10.1002/jmv.26964.

82. Takashita E, Kawakami C, Momoki T, Saikusa M, Shimizu K, Ozawa $\mathrm{H}$, et al. Increased risk of rhinovirus infection in children during the coronavirus disease-19 pandemic. Influenza Other Respir Viruses. 2021 Mar 14. https://doi.org/10.1111/irv.12854.

83. Lier AJ, Tuan JJ, Davis MW, Paulson N, McManus D, Campbell $\mathrm{S}$, et al. Disseminated strongyloidiasis in a patient with COVID19. Am J Trop Med Hyg. 2020;103(4):1590-2.

84. Mohamed MFH, Mohamed SF, Yousaf Z, Kohla S, Howady F, Imam Y. COVID-19 unfolding filariasis: the first case of SARSCoV-2 and Wuchereria bancrofti coinfection. PLoS Negl Trop Dis. 2020;14(11):e008853.

85. Molina I, Marcolino MS, Pires MC, Ramos LER, Silva RT, Guimarãres Júnior MH, et al. Chagas disease and SARS-CoV-2 coinfection does not lead to worse in-hospital outcomes: results from the Brazilian COVID-19 Registry. medRxiv. 2021. https:/ doi.org/10.1101/2021.03.22.21254078.

86. Gebrecherkos T, Gessesse Z, Kebede Y, Gebreegzabher A, Tasew G, Abdulkader M, et al. Effect of co-infection with parasites on severity of COVID-19. medRxiv. 2021. https://doi.org/10.1101/ 2021.02.02.21250995. 
87. Shah AS, Heidari A, Civelli VF, Sharma R, Clark CS, Munoz AD, et al. The coincidence of 2 epidemics, coccidioidomycosis and SARS-CoV-2: a case report. J Investig Med High Impact Case Rep. 2020;8:2324709620930540.

88. White PL, Dhillon R, Cordey A, Hughes H, Faggian F, Soni S, et al. A national strategy to diagnose COVID-19 associated invasive fungal disease in the ICU. Clin Infect Dis. 2020;ciaa1298. https://doi.org/10.1093/cid/ciaa1298.

89. Salmanton-Garcia J, Sprute R, Stemler J, Bartoletti M, Dupont D, Valerio M, et al. COVID-19-associated pulmonary aspergillosis, March-August 2020. Emerg Infect Dis. 2021;27(4):-1086. https:// doi.org/10.3201/eid2704.204895.

90. Prestel C, Anderson E, Forsberg K, Lyman M, de Perio MA, Kuhar D, et al. Candida auris outbreak in a COVID-19 specialty care unit - Florida, July-August 2020. MMWR Morb Mortal Wkly Rep. 2021;70(2):56-7.

91. Lamoth F, Lewis RE, Walsh TJ, Kontoyiannis DP. Navigating the uncertainties of COVID-19 associated aspergillosis (CAPA): a comparison with influenza associated aspergillosis (IAPA). J Infect Dis. 2021:jiab163. https://doi.org/10.1093/infdis/jiab163.

92. Rabagliati R, Rodríguez N, Núñez C, Huete A, Bravo S, Garcia P. COVID-19-associated mold infection in critically ill patients. Chile. Emerg Infect Dis. 2021;27(5). https://doi.org/10.3201/ eid2705.204412.

93. Gouzien L, Cocherie T, Eloy O, Legriel S, Bedos J-P, Simon C, et al. Invasive aspergillosis associated with severe COVID-19 19: a word of caution. Infect Dis Now. 2021. https://doi.org/10.1016/j. idnow.2020.12.008.

94. Arashiro T, Nakamura S, Asami T, Mikuni H, Fujiwara E, Sakamoto S, et al. SARS-CoV-2 and Legionella co-infection in a person returning from a Nile cruise. J Travel Med. 2020;27(3): taaa053.

95. Elzein F, Alsherbeeni N, Almatrafi K, Shosha D, Naoufel K. COVID-19 co-infection in a patient with Brucella bacteremia. Respir Med Case Rep. 2020;31:101183.

96. Stochino C, Villa S, Zucchi P, Parravicini P, Gori A, Raviglione MC. Clinical characteristics of COVID-19 and active tuberculosis co-infection of an Italian reference hospital. Eur Respir J. 2020;56(1):2001708.

97. Sandhu A, Tillotson G, Polistico J, Salimnia H, Cranis M, Moshos $\mathrm{J}$, et al. Clostridioides difficile in COVID-19 patients, Detroit, Michigan, USA, March-April 2020. Emerg Infect Dis. 2020;26(9):2272-4.

98. Granata G, Bartoloni A, Codeluppi M, Contadini I, Cristini F, Fantoni M, et al. The burden of Clostridioides difficile infection during the COVID-19 pandemic: a retrospective case-control study in Italian hospitals (CloVid). J Clin Med. 2020;9(12):E3855.

99. Lewandowski K, Rosolowski M, Kaniewska M, Kucha P, Meler A, Wierzba W, et al. Clostridiodes difficile infection in coronavirus disease 2019; an underestimated problem? Pol Arch Inter Med. 2020. https://doi.org/10.20452/pamw.15715.

100. He F, Xia X, Nie D, Yang H, Jiang Y, Huo X, et al. Respiratory bacterial pathogen spectrum among COVID-19 infected and nonCOVID-19 virus infected pneumonia patients. Diagn Microbiol Infect Dis. 2020;98(4):115199.

101. Le Roux P, Millardet E, Duquenoy A, Labbé F, Vandendriessche A. Pleuropneumonia resulting from varicella and COVID-19 coinfection in a 10-month-old infant. Arch Paediatr. 2020;27(8): 509-10.

102. Amaral PH, McFerreira BM, Roll S, Dmm Neves P, Ga Pivetta L, Mohrbacher S, et al. COVID-19 and cytomegalovirus co-infection: a challenging case of a critically ill patient with gastrointestinal symptoms. Eur J Case Rep Intern Med. 2020;7(10):001911.

103. Wee LE, Cherng BPZ, Conceicao EP, Goh KC-M, Wan WY, Ko KKK, et al. Experience of a tertiary hospital in Singapore with management of a dual outbreak of COVID-19 and dengue. Am J
Trop Med Hyg. 2020;103:2005-11. https://doi.org/10.4269/ ajtmh.20-0703.

104. Johnston R. The first 6 months of HIV-SARS-CoV-2 coinfection: outcomes for 6947 individuals. Curr Opin HIV AIDS. 2020;16: 54-62. https://doi.org/10.1097/COH.0000000000000654.

105. Hu R, Yan H, Liu M, Kong W, Zhu Z, Liu P, et al. Virologic and immunologic outcomes for HIV patients with coronavirus disease 2019. J Acquir Immune Defic Syndr. 2020;86:213-8. https://doi. org/10.1097/QAI.0000000000002540.

106. Nagarakanti SR, Okoh AK, Grinberg S, Bishburg E. Clinical outcomes of patients with COVID-19 and HIV coinfection. J Med Virol. 2020. https://doi.org/10.1002/jmv.26533.

107. Ali E, Ziglam H, Kohla S, Ahmed M, Yassin M. A case of fulminant liver failure in a 24-year-old man with coinfection with hepatitis B virus and SARS-CoV-2. Am J Case Rep. 2020;21: e925932.

108. Wu J, Yu J, Li W, Song S, Zhao L, Zhao X, et al. Epidemiological and clinical characteristics of 70 cases of coronavirus disease and concomitant hepatitis B virus infection: a multicentre descriptive study. J Viral Hepat. 2020;28:80-8. https://doi.org/10.1111/jvh. 13404.

109. Liu R, Zhao L, Cheng X, Huan H, Li C, Li D, et al. Clinical characteristics of COVID-19 patients with hepatitis B virus infection - a retrospective study. Liver Int. 2020;41:720-30. https://doi. org/10.1111/liv.14774.

110. Riou C, du Bruyn E, Stek C, Daroowala R, Goliath RT, Abrahams $\mathrm{F}$, et al. Profile of SARS-CoV-2-specific CD4 T cell response: relationship with disease severity and impact of HIV-1 and active Mycobacterium tuberculosis co-infection. MedRxiv. 2021. https:// doi.org/10.1101/02.16.21251838.

111. Simonnet A, Englemann I, Moreau A-S, Garcia B, Six S, El Kalioubie A, et al. High incidence of Epstein-Barr virus, cytomegalovirus, and human-herpes virus-6 reactivations in critically-ill patients with COVID-19. Infect Dis Now. 2021. https://doi.org/ 10.1016/j.idnow.2021.01.005.

112. Tesoriero JM, Swain C-AF, Pierce JL, Zamboni L, Wu M, Holtgrave DR, et al. COVID-19 outcomes among persons living with or without diagnosed HIV infection in New York State. JAMA Netw Open. 2021;4(2):e2037069.

113. Laracy J, Zucker J, Castor D, McMahon DJ, Guo TW, Yan M, et al. HIV-1 infection does not change disease course or inflammatory pattern of SARS-CoV-2-infected patients presenting at a large urban medical center in New York City. Open Forum Infect Dis. 2021;8(2):ofab029.

114. Mangia A, Cenderello G, Verucchi G, Ciancio A, Fontana A, Piazzolla $\mathrm{V}$, et al. Is positivity for hepatitis $\mathrm{C}$ virus antibody predictive of lower risk of death in COVID-19 patients with cirrhosis? World J Clin Cases. 2020;8(22):5831-4.

115. Rueca M, Fontana A, Barolini B, Piselli P, Mazzarelli A, Copetti $\mathrm{M}$, et al. Investigation of nasal/oropharyngeal microbial community of COVID-19 patients by $16 \mathrm{~S}$ rDNA sequencing. Int $\mathrm{J}$ Environ Res Public Health. 2021;18(4):2174.

116. Merenstein C, Liang G, Whiteside SA, Cobián-Gümes AG, Merlino MS, Taylor LJ, et al. Signatures of COVID-19 severity and immune response in the respiratory tract microbiome. medRxiv. 2021. https://doi.org/10.1101/2021.04.02.21254514.

117. Ventero MP, Cuadrat RRC, Vidal I, Andrade BGN, MolinaPardines C, Haro-Moreno JM, et al. Nasopharyngeal microbial communities of patients infected with SARS-CoV-2 that developed COVID-19. Front Microbiol. 2021;12:637430.

118. Ripa M, Galli L, Poli A, Oltolini C, Spagnuolo V, Mastrangelo A, et al. Secondary infections in patients hospitalized with COVID19: incidence and predictive factors. Clin Microbiol Infect. 2020;S1198-743X(20)30652-2. https://doi.org/10.1016/j.cmi. 2020.10.021. 
119. Bork JT, Leekha S, Claeys K, Seung H, Tripoli M, Amoroso A, et al. Change in hospital antibiotic use and acquisition of multidrug resistant Gram-negative organisms after the onset of coronavirus disease 2019. Infect Control Hosp Epidemiol. 2020;10:1-13. https://doi.org/10.1017/ice.2020.1360.

120. Cheng LS-K, Chau SK-Y, Tso EY-K, Tsang SW-C, Li IY-F, Wong BK-C, et al. Bacterial co-infections and antibiotic prescribing practice in adults with COVID-19: experience from a single hospital cluster. Ther Adv Infect Dis. 2020;7:2049936120978095. https://doi.org/10.1177/2049936120978095.

121. Cong W, Poudel AN, Alhusein N, Wang H, Yao G, Lambert H. Antimicrobial use in COVID-19 patients in the first phase of the SARS-CoV-2 pandemic: rapid review and evidence synthesis. medRxiv. 2021. https://doi.org/10.1101/2021.02.16.21251932.

122. Mostafa HH, Fissel JA, Fanelli B, Bergman Y, Gniazdowski V, Dadlani M, et al. Metagenomic next-generation sequencing of nasopharyngeal specimens collected from confirmed and suspect COVID-19 patients. mBio. 2020;11(6):e01969-20.

123. Perez S, Innes GK, Spalding Walters M, Mehr J, Arias J, et al. Increase in hospital-acquired carbapenem-resistant Acinetobacter baumanii infection and colonization in an acute care hospital during a surge in COVID-19 admissions - New Jersey, February-July 2020. MMWR Morb Mortal Wkly Rep. 2020;69(48):1827-31.

124. Belvisi V, Del Borgo C, Vita S, Redaelli P, Dolce P, Pacella D, et al. Impact of severe acute respiratory syndrome coronavirus-2 (SARS-CoV-2) pandemic on carbapenemase-producing Klebsiella pneumoniae (KPC-Kp) prevention and control program: convergent or divergent action? J Hosp Infect. 2020;S0195-6701(20)30569-7. https://doi.org/10.1016/j.jhin. 2020.11.030.

125. Massey BW, Jayathilake K, Meltzer HY. Respiratory microbial co-infection with SARS-CoV-2. Front Microbiol. 2020;11:2079. https://doi.org/10.3389/fmicb.2020.02079.

126. Lv Z, Cheng S, Le J, Huang J, Feng L, Zhang B, et al. Clinical characteristics of 354 hospitalized patients with COVID-19 in Wuhan, China: a retrospective cohort study. Microbes Infect. 2020;22(4-5):195-9.

127. Contou D, Claudinon A, Pajot O, Micaëlo M, Longuet Flandre P, Dubert $\mathrm{M}$, et al. Bacterial and viral co-infections in patients with severe SARS-CoV-2 pneumonia admitted to a French ICU. Ann Intensive Care. 2020;10(1):119.

128. Youngs J, Wyncoll D, Hopkins P, Arnold A, Ball J, Bicanic T. Improving antibiotic stewardship in COVID-19: bacterial coinfection is less common than with influenza. J Infect. 2020;81(3):e55-7.

129. Kolenda C, Ranc A-G, Boisset S, Caspar Y, Carricajo A, Souche A, et al. Assessment of respiratory bacterial coinfections among Severe Acute Respiratory Syndrome coronavirus 2-positive patients hospitalized in intensive care units using conventional culture and BioFire, FilmArray Pneumonia Panel Plus assay. Open Forum Infect Dis. 2020;7(11):ofaa484.

130. Gottschalk J, von Graevenitz A. Chapter 1. A role for microscopy continues. In: Cimolai N - ed. Laboratory Diagnosis of Bacterial Infections. Marcel Dekker, Inc., New York, USA, 2001. pp. 1-7.

131. Townsend L, Hughes G, Kerr C, Kelly M, O'Connor R, Sweeney $\mathrm{E}$, et al. Bacterial pneumonia coinfection and antimicrobial therapy duration in SARS-CoV-2 (COVID-19) infection. JAC Antimicrob Resist. 2020;2(3):dlaa071.

132. Cruz Soriano M, Vaquero C, Ortiz-Fernández A, Caballero A, Blandino-Ortiz A, de Pablo R. Low incidence of co-infection, but high incidence of ICU-acquired infections in critically ill patients with COVID-19. J Infect. 2020;11:33-e21. https://doi.org/ 10.1016/j.jinf.2020.09.010.

133. Karami Z, Knoop BT, Dofferhoff ASM, Blaauw MJT, Janssen NA, van Apeldoorn M, et al. Few bacterial co-infections but frequent empiric antibiotic use in the early phase of hospitalized patients with COVID-19: results from a multicenter retrospective cohort study in the Netherlands. Infect Dis. 2020;24:1-9. https:// doi.org/10.1080/23744235.2020.1839672.

134. Wang L, Amin AK, Khanna P, Aali A, McGregor A, Bassett P, et al. An observational cohort study of bacterial co-infection and implications for empirical antibiotic therapy in patients presenting with COVID-19 to hospitals in north west London. J Antimicrob Chemother. 2020:dkaa475. https://doi.org/10.1093/jac/dkaa475.

135. Nori P, Szymczak W, Puius Y, Sharma A, Cowman K, Gialanella P, et al. Emerging co-pathogens: New Delhi metallo-betalactamase producing Enterobacterales infections in New York City COVID-19 patients. Int J Antimicrob Agents. 2020;25: 106179. https://doi.org/10.1016/j.ijantimicag.2020.106179.

136. Rothe K, Feihl S, Schneider J, Wallnöfer F, Wurst M, Lukas M, et al. Rates of bacterial co-infections and antimicrobial use in COVID-19 patients: a retrospective cohort study in light of antibiotic stewardship. Eur J Clin Microbiol Infect Dis. 2020;2:1-11. https://doi.org/10.1007/s10096-020-04063-8.

137. Sharifipour E, Shams S, Esmkhani M, Khodadadi J, FotouchiArdakani R, Koohpaei A, et al. Evaluation of bacterial coinfections of the respiratory tract in COVID-19 patients admitted to ICU. BMC Infect Dis. 2020;20(1):646.

138. Li J, Wang J, Yang Y, Cai P, Cao J, Cai X, et al. Etiology and antimicrobial resistance of secondary bacterial infections in patients hospitalized with COVID-19 in Wuhan, China: a retrospective analysis. Antimicrob Resist Infect Control. 2020;9(1):153.

139. Nori P, Cowman K, Chen V, Bartash R, Szymczak W, Madaline $\mathrm{T}$, et al. Bacterial and fungal coinfections in COVID-19 patients hospitalized during the New York City pandemic surge. Infect Control Hosp Epidemiol. 2020;24:1-5. https://doi.org/10.1017/ ice.2020.368.

140. Poretta AD, Baggiani A, Arzilli G, Casigliani V, Mariotti T, Mariottini F, et al. Increased risk of acquisition of New Delhi metallo-beta-lactamase-producing carbapenem-resistant Enterobacteriales (NDM-CRE) among a cohort of COVID-19 patients in a teaching hospital in Tuscany, Italy. Pathogens. 2020;9(8):635

141. Verroken A, Scohy A, Gérard L, Wittebole X, Collienne C, Laterre P-F. Co-infections in COVID-19 critically ill and antibiotic management: a prospective cohort analysis. Critical Care. 2020;24(1):410.

142. Coppola S, Ciabattoni A, Pozzi T, Castagna V, Bassi GL, Chiumello D. Hazardous mismatch between pulmonary pathogens and antibiotic treatments in COVID-19 patients. Br J Anaesth. 2020;125(4):e380-2.

143. Elabbadi A, Turpin M, Gerotziafas GT, Teulier M, Voiriot G, Fartoukh M. Bacterial coinfection in critically ill COVID-19 patients with pneumonia. Infection. 2021. https://doi.org/10.1007/ s15010-020-01553-x.

144. Ramadan HK-A, Mahmoud MA, Zakaria Aburahma M, Elkhawaga AA, El-Mohktar MA, Sayed IM, et al. Predictors of severity and co-infection resistance profile in COVID-19 patients: first report from upper Egypt. Infect Drug Resist. 2020;13:340922.

145. Kokkoris S, Papachatzakis I, Gavrielatou E, Ntaidou T, Ischaki E, Malachias S, et al. ICU-acquired blood stream infections in critically ill patients with coronavirus disease-19. J Hosp Infect. 2020;S0195-6701(20)30523-5. https://doi.org/10.1016/j.jhin. 2020.11.009.

146. Mahmoudi H. Bacterial co-infections and antibiotic resistance in patients with COVID-19. GMS Hyg Infect Control. 2020;15: Doc35. https://doi.org/10.3205/dgkh000370.

147. Magnasco L, Mikulska M, Giacobbe DR, Taramasso L, Vena A, Dentone C, et al. Spread of carbapenem-resistant Gram-negatives and Candida auris during the COVID-19 pandemic in critically ill 
patients: one step back in antimicrobial stewardship? Microorganisms. 2021;9(1):E95.

148. Hosoda T, Harada S, Okamoto K, Ishino S, Kaneko M, Suzuki M, et al. COVID-19 and fatal sepsis caused by hypervirulent Klebsiella pneumoniae, Japan, 2020. Emerg Infect Dis. 2020;27(2):-559. https://doi.org/10.3201/eid2702.204662.

149. Segrelles-Calvo G, de S Araújo GR, Llopis-Pastor E, Carrillo J, Hernández-Hernández M, Rey L, et al. Prevalence of opportunistic invasive aspergillosis in COVID-19 patients with severe pneumonia. Mycoses 2020 20. doi: https://doi.org/10.1111/myc. $13219,144,151$

150. Machado M, Valerio M, Álvarez-Uria A, Olmedo M, Veintimilla C, Padilla B, et al. Invasive pulmonary aspergillosis in the COVID-19 era: an expected new entity. Mycoses. 2020. https:// doi.org/10.1111/myc.13213.

151. Dellière $\mathrm{S}$, Dudoignon E, Fodil S, Voicu S, Collet M, Oillic P-A, et al. Risk factors associated with COVID-19-associated pulmonary aspergillosis in ICU patients: a French multicentric retrospective cohort. Clin Microbiol Infect. 2020:S1 198-743X(20)30756-4. https://doi.org/10.1016/j.cmi.2020.12.005.

152. Kreitmann L, Monard C, Dauwalder O, Simon M, Argaud L. Early bacterial co-infection in ARDS related to COVID-19. Intensive Care Med. 2020;46(9):1787-9.

153. Payson A, Etinger V, Napky P, Montarroyos S, Ruiz-Castaneda A, Mestre M. Risk of serious bacterial infections in young febrile infants with COVID-19. Pediatr Emerg Care. 2021;37(4):232-6.

154. Zhang G, Hu C, Luo L, Fang F, Chen Y, Li J, et al. Clinical features and short-term outcomes of 221 patients with COVID19 in Wuhan, China. J Clin Virol. 2020;127:104364. https://doi. org/10.1016/j.jcv.2020.104364.

155. Goncalves Mendes Neto A, Lo KB, Wattoo A, Salacup G, Pelayo J, DeJoy R III, et al. Bacterial infections and patterns of antibiotic use in patients with COVID-19. J Med Virol. 2020. https://doi.org/ 10.1002/jmv.26441, https://doi.org/10.1002/j.26441.

156. Bhatt PJ, Shiau S, Brunetti L, Xie Y, Solanki K, Khalid S, et al. Risk factors and outcomes of hospitalized patients with severe COVID-19 and secondary bloodstream infections: a multicenter, case-control study. Clin Infect Dis. 2020. https://doi.org/10.1093/ cid/ciaa1748.

157. Karruli A, Boccia F, Gagliardi M, Patauner F, Ursi MP, Sommese $\mathrm{P}$, et al. Multidrug-resistant infections and outcome of critically ill patients with Coronavirus Disease 2019: a single center experience. Microb Drug Resist. 2021. https://doi.org/10.1089/ mdr.2020.0489.

158. Buehler PK, Zinkernagel AS, Hofmaenner DA, Wendel Garcia PD, Acevedo CT, Gómez-Mejia A, et al. Bacterial pulmonary superinfections are associated with longer duration of ventilation in critically ill COVID-19 patients. Cell Rep Med. 2021 Mar;14: 100229. https://doi.org/10.1016/j.xcrm.2021.100229.

159. Patel A, Emerick M, Cabunac MK, Williams MH, Preas MA, Schrank G, et al. Rapid spread and control of multidrug-resistant Gram-negative bacteria in COVID-19 patient care units. Emerg Infect Dis. 2021;27(4):-1237. https://doi.org/10.3201/eid2704. 204036.

160. Baiou A, Elbuzidi AA, Bakdach D, Zaqout A, Alarbi KM, Bintaher AA, et al. Clinical characteristics and risk factors for the isolation of multidrug-resistant Gram-negative bacteria from critically ill patients with Coronavirus Disease 2019. J Hosp Infect. 2021;S0195-6701(21)00047-5. https://doi.org/10.1016/j. jhin.2021.01.027.

161. Haedo M, Melendi SE, Lauko Mauri M, Ujeda C, Leis R. Usefulness of blood cultures in COVID-19 pneumonia. Medicina. 2020;80(Suppl 6):44-7.

162. Thelen JM, Buenen AGN, van Apeldoorn M, Wertheim HF, Hermans MHA, Wever PC. Community-acquired bacteraemia in COVID-19 in comparison to influenza A and influenza B: a retrospective cohort study. BMC Infect Dis. 2021;21(1):199.

163. Cusumano JA, Dupper AC, Malik Y, Gavioli EM, Banga J, Caban AB, et al. Staphylococcus aureus: bacteremia in patients infected with COVID-19: a case series. Open Forum Infect Dis. 2020;7(11):ofaa518.

164. Gysin M, Tirsa Acevedo C, Haldimann K, Bodendoerfer E, Imkamp F, Bulut K, et al. Antimicrobial susceptibility patterns of respiratory Gram-negative bacterial isolates from COVID-19 patients in Switzerland. medRxiv. 2021. https://doi.org/10.1101/ 2021.03.10.21253079.

165. Cimolai N. Transparency of disinfectant and hand sanitizer contents in the context of COVID-19. Eur Rev Med Pharmacol Sci. 2021;25(6):2464-7.

Publisher's Note Springer Nature remains neutral with regard to jurisdictional claims in published maps and institutional affiliations. 